\title{
Oral Communicative Competence of Primary School Students
}

\author{
Isabel Cantón Mayo ${ }^{1}$ \& Elena Pérez Barrioluengo ${ }^{1}$ \\ ${ }^{1}$ Facultad de Educación, Campus de Vegazana, Universidad de León, León, Spain \\ Correspondence: Isabel Cantón Mayo, Facultad de Educación, Campus de Vegazana, 24071, León, Spain. \\ E-mail: icanm@unileon.es
}

Received: March 28, 2017

Accepted: April 29, 2017

Online Published: May 24, 2017

doi:10.5539/jel.v6n4p57

URL: http://doi.org/10.5539/jel.v6n4p57

\begin{abstract}
Oral communicative competence enables speakers of a language to interact effectively with each other. Oral communicative competence includes a wide semantic field since the oral expression is a way of expression for the thought and it provides feedback and develops by means of the linguistic function (Vygotsky, 1992; Piaget, 1983a, 1983b; Pinker, 2003). English communicative competence is based on the use of the language as a tool of communication, both oral and written, of representation, of interpretation and of reality comprehension. This investigation aims to analyse the oral communicative competence in English of students who have finished the stage of Primary Education. It also tries to know if the center where students study, the students' gender, the attitude towards the English language and attendance to private lessons increase the oral communicative competence. The sample was intentional and stratified (rural-urban and ordinary-bilingual). It is composed by 265 students and the instrument is a questionnaire provided with reliability and validity. The results show high levels of competence, higher than expected, and with light differences that favor the girls and the urban bilingual schools in the acquisition of the oral communicative competence in English.
\end{abstract}

Keywords: bilingual schools, oral competence in English, Primary Education, rural schools, urban schools

\section{Introduction and Justification}

Similar terms such as skill or capacity have usually been associated with competence, features that a person possesses and can or not be used at a given time. The concept of competence registers in a wide semantic field, which provokes relations of dependence both in its definition and in its application, with other similar concepts. A competent person can have certain skills or can acquire them by instruction or learning. There is, nevertheless, a difference between skill and competence, since the competence relates to behaviours observed (Stoof, Marten, Go Merrienboer, \& Bastiens, 2002) and the competence with actions. Words like skill, capacity and action are used like synonymous of competence, whereas knowledge, skill and attitude are part of the competence. Westera (2001, p. 6) defines competence as "higher order cognitive skills and behaviours that represent the ability to cope with complex, unpredictable situations". So, competence includes other processes such as metacognition and the strategic thought and presupposes an intention and conscious use of both. To reach competences implies being an expert apprentice and lifelong learning, to adapt to a world in continuous change (Branches \& Luque, 2010). The OCDE Program Definition and Selection of Competences (DeSeCo) alludes to the achievement of a high degree of integration between the capacities and the extent of social aims that an individual has when pointing out that the competence is more than knowledge and skills. It also includes the skill of facing complex demands, relying on and mobilizing psychosocial resources (including skills and attitudes) in a particular context (OECD, 2003, p. 3). Noguera (2004) and Fernandez-Salinero (2006) offer a definition of competence in linguistic terms, indicating the combination of attributes that concern diverse orders of the person related to: a) the knowledge, aptitudes and technical skills (to know); b) the methodological ways of proceeding in an activity (to be able to do); c) the guidelines and individual and collective forms of behaviour (to be able to be); d) the forms of organization and interaction (to be able to be) (Fernandez-Salinero, 2006, p. 141). In Spain, like in the rest of the European countries, competences are included in the regulation and so, the Organic Law of Education of 2006 (LOE) and the Organic Law for the Improvement of the Educational Quality of 2013 (LOMCE) include them in his preamble and text. Perrenoud (2012) indicates that the fascination for the competencies and their incorporation in the educational systems is not only due to the influence of the economic and European institutions, but they have also adapted to the global character, and the demanding society we live in, the new technologies, the ways of life and work (Perrenoud, 2012, p. 39). We have went through a review of the term 
competence to extract, based on Corominas (2006), some common characteristics of the concept competence: it is related to the action; it develops and gets up-to-date in the action; it is linked to a context, to an established situation; it integrates different elements, such as knowledge, procedures and attitudes; it facilitates the effective resolution of different situations and it is teachable. In this article, the competence is understood as conscious and reflexive use of knowledge, skills and attitudes for the resolution of a certain problem with capacity of adjustment to the different conditions and capable of being used in different areas or situations.

\section{Linguistic Communicative Competence}

The term competence is one of the most questionable terms in the field of general and applied linguistics. Its introduction to linguistic discourse has been generally associated with Chomsky who defines the language as a set of phrases, each of them with a finite duration and constructed from a finite number of elements (Chomsky, 1957). The oral expression turns into a way of expression for the thought and at the same time, it feeds back and develops by means of the linguistic function (Vygotsky, 1992; Piaget, 1983a, 1983b; Pinker, 2003). "Speaking is having something to say and to be able to say it; to find the words, to construct the phrases well, to give them their own expression. Then, it is when the communication is easy, always considering as everything what is said, how it is said and to whom it is said” (Aymerich, 1971, p. 61). For Sapir, the language is purely human and it is a not instinctive method of communication of ideas, emotions and desires, by means of symbols produced voluntarily (Sapir, 1921). Nowadays, the language is considered to be a way of communication in which two or more participants interact. The linguistic communicative competence refers to the use of language as an oral and written instrument of communication, of representation, interpretation and comprehension of the reality, of construction and communication of the knowledge and of organization and auto regulation of the thought, the emotions and the behaviour. We emphasize that the orality and its education have strong resistances on students. Zuccherini (1992) indicates some of the reasons from the school resistance to the spoken language as the difficulties of permanency, of reflection, of uniformity, that produce major weariness and distraction. Other authors (Díaz, 2006, p. 23) indicate problems in the acquisition of the oral competence because of the evolutionary dimension of the language and of the competence's generality.

At educational level, to be able to acquire the oral competence would be necessary a continued practice of the oral expression, from the infancy up to the conclusion of the studies, adapted to the age of the pupils (Canes, 2000; Lopez Valero \& Encabo, 2001; Palou \& Bosch, 2005; Quiles, 2006). The school must develop in the pupil this capacity and evaluate it (Murillo, Martínez, \& Nobleman, 2014), since the current society demands interactions that need the oral expression in public.

Although there has been more effort to develop the written competence at education, nowadays the communicative approach and the orality has been more considered (Quiles, 2006). Though, as Monfort (1995) indicates, "it is not very sure nevertheless that this change has overcome the simple abstract level of the definition of aims and of the good desires to reach the level of real changes in the practices in each of the educational levels". Some authors like Canale and Swain (1980) specify that the communicative competence is integrated by four competencies: linguistics, sociolinguistics, strategic and discursive. In our case we focus on the oral part that includes, mainly the four mentioned competencies.

To sum up, the basic competence in linguistic communication involves a set of knowledge, skills and attitudes that are interrelated and rely on the communicative act. The knowledge is absolutely necessary for the reflection on the functioning of the language and its procedure of use. The knowledge is classified on linguistic, sociolinguistic and pragmatic knowledge of the language. The skills are the necessary abilities to listen to and to understand the different speeches, as well as to formulate the ideas across the oral language. They are included inside the skills, the necessary strategies to regulate the communicative exchange, the skills to read and to understand texts, as well as to write diverse types of texts with varied intentions. The attitudes favor the listening, the contrast of different opinions and the respect towards the opinions of others. They also favor the interest for the intercultural communication (Documento Currículo y Competencias Básicas, Ministerio de Educación, 2006).

\section{Oral Communication in a Foreign Language}

The linguistic communicative competence in English has also been the object of a theoretical review that we synthesize in the following lines based on Nikeva and Curtain Perez's works (2014). The linguistic communicative competence in English relies on the use of the language as a tool of communication, both oral and written, of representation, of interpretation and of comprehension of the reality. Also it can be understood as an element of construction and communication of the knowledge or as an instrument of organization and autoregulation of the thought, the emotions and the behaviour. According to Perez Esteve (2008, p. 43) "to be 
competent in linguistic communication means to possess the necessary resources to take part, by means of the language, in the different spheres of the social life". Two outstanding authors in the teaching of English were Chomsky (1965) and Hymes (1971), the first one as a reference in linguistic competence and the second one based on the communicative competence.

The Council of Europe with the creation of the Common European Framework of Reference for Languages: learning, teaching and assessment (2002) for the unification of directives in the learning and education of the languages, proposes orientations by means of linguistic guidelines to achieve the communication in the teaching-learning process of a language. The document specifies, in a general way, the principal capacities of the communication in the mother language. It is based on the skills to understand, to express and to interpret thoughts, feelings and facts of oral and written forms (listening, speaking, reading and writing) in a wide range of social contexts (personal and professional life, leisure and education), in agreement with the desires or needs of each person. It is an illustrative document and it has turned into an international reference for all the professionals related to the education of foreign languages providing "a common basis for the elaboration of language syllabuses, curriculum guidelines, examinations and textbooks across Europe" (Consejo de Europa, 2002, p. 1). It also refers to the learning and use of foreign languages as constructed on the general and communicative competences of the language of the individuals and that they facilitate them the development of multilingual and multicultural competencies (Comisión Europea, 2004). The document describes in an integrated form what the students of languages have to learn to do in order to use a language to communicate, as well as the knowledge and skills that they have to develop to be able to act in an effective way. The approach of the Common European Framework of Reference for Languages (Consejo de Europa, 2002, p. 9) is based on an "action-oriented one in so far as it views users and learners of a language primarily as social agents". In the Common European Framework of Reference for Languages the acquisition of a language is contextualised with specific aims of communication and with the pretension to give response to the needs that from an intercultural Europe, it is needed to learn in the classrooms beyond linguistic contents. It contains three levels: proficient user, independent user and basic user, depending on their communicative development, being the first one of total domain, the second one of a correct use and the third one of a beginning use.

The aim of the Spanish educational system referred to the learning of a foreign language in Primary Education is very practical, since it aims the student to be able to communicate in the above mentioned language. But the communication in a language carries different skills such as listening, reading, writing and speaking. These four linguistic skills are classified into receptive skills, listening and reading, and productive skills, speaking and writing.

This is well described as a principal of the Spanish educational system in the Organic Law of Education: "the training for the communication in one or more foreign languages" (LOE, cap. I, art. I) and in the current Organic Law for the Improvement of the Educational Quality: "to achieve that the students unroll fluently at least in one foreign language" (LOMCE, Preámbulo XII). It divides them into knowledge (discursive, oral, writings, uses), skills (expression, argumentation, adjustment, verbalization, conversation) and attitudes (listening, contrast, confidence, interpretation, comprehension and relation). The framework is formed by one of the most important contributions for the Didactics of the Languages-Cultures, especially for the school contexts, where it cannot be considered to be a foreign element to the set of the components of the curriculum of languages (García Doval et al., 2004, p. 78). Following these recommendations and components, a study of detection of the level of oral competence of the Spanish pupils when they finish the stage of Primary Education has been carried out.

\section{Methodology}

This study of investigation is based on the non-experimental methodology (Latorre \& Arnal, 2005) and to be more specific, it is an ex-post fact investigation (Bisquerra, 1989; Arnal, Del Rincón, \& Latorre, 1992; Buendía, Colás, \& Hernández, 1998; Latorre et al., 2005) prospective type (Colás, Buendía, \& Pina, 2009) since the independent variables cannot be manipulated but analyzed to determine in what degree they influence the dependent variables. The methodology of our study is therefore descriptive and interpretive. Tejedor (1999) indicates that the most used methodology inside the investigation in education is of descriptive type. Whereas Creswell (2002) understands the descriptive studies of investigation as the ones in which the investigator applies a certain instrument to a representative sample of the population in order to study certain attitudes, behaviors or characteristics of it. This is the motive why we have selected this methodology.

The general aim of the study is to analyse the level of achievement in oral communicative competence in English acquired by the students at the end of the Primary Education of León's Province. The specific aims would be four: to establish the level of expression and oral interaction in English of the students of sixth course of Primary 
Education in León's Province; to know if differences exist in the level acquired in linguistic communicative competence in English between ordinary and bilingual schools; to determine differences in the level of achievement of the linguistic communicative competence in English between male pupils and female pupils and to establish if the pupils who dedicate more time to the revision and study of the English language will obtain better results in the acquisition of the linguistic communicative competence.

In relation to the sample of this investigation, the population or universe are the pupils of sixth course of Primary Education of all the public centers (131 centers) of León's Province. Inside the dilemma between non-probability sample and intentional sample, it has been chosen the second one following a strategical criteria where the individuals are related to the characteristics of the investigation and provide very relevant information for the object of our study (Hernández Pina, Maquilón Sanchez, \& Cuesta Sáez de Tejada, 2008). This way we manage to represent the different typology that we wanted to analyse (non probability-intentional sample) including the different zones that are part of León's province (representative geographical sample). We emphasize that in León's city there are 18 schools of which 12 have bilingual education, one has the linguistic section and only five are ordinary schools. The present study took into account the number of public schools object of analysis and this way, it was carried out in six schools of the capital of the province and one in Bembibre, as representative of the region called El Bierzo; two schools of the region called Maragatería and five of the area called Ribera. The zone of Riaño's mountains with 15,956 inhabitants is represented by three schools; Laciana's Valley and the south of the province by other two schools. Sahagún with 7,057 inhabitants, is represented by a public school. The region Esla-Campos, in the south-east of the province with 26,391 inhabitants, is represented by a public school too.

The withdrawal of information was personal, we talked to the heads of the schools and the English teachers of sixth course of Primary Education to ask for their collaboration in the study and to know their availability to form part of the investigation. The sample remained constituted as follows, public urban schools: two ordinary schools and five bilingual schools; public rural schools: eleven ordinary schools and 5 bilingual schools. There are 19 public bilingual schools and 18 ordinary teaching schools in the sample. With regard to the evaluated pupils, the sample remained composed by a total of 265 individuals with ages between 11 and 13 years old, being the average of these pupils 11.54 years and its mode 11 (128 students). According to gender, it is observed that there is an equitable distribution between male pupils and female pupils, though lightly superior for the female pupils. The $45.3 \%$ are boys (120 students) and the $54.7 \%$ are girls (145 students).

The instrument was a test of evaluation named COBAIO (Basic Competence in Oral English). It was used to analyse the linguistic communicative oral competence in English at the end of Primary Education. It consists of a questionnaire with some information about the students' context, in which descriptive information is gathered, fundamentally about their personal information, their family, their dedication to the study of the subject, and also concerning the attitude towards the subject and the teacher, and a test for the evaluation of the oral expression and interaction that adjusts to the contents gathered in the legal text. The educational legislation was checked and instruments already elaborated were analysed, such as the tests named Cambridge English: Young Learners, which are a series of English entertaining and motivating examinations designed for students of Primary Education. In order to evaluate the oral skills the tasks were Personal questions and John's typical day respectively, designed to evaluate the oral production in the last course of Primary Education. This test besides evaluating the skill of oral expression and oral interaction of the linguistic communicative competence in English, connects with the curriculum (Decree 40/2007) of Primary Education, concretely with the Block of content 1: listening, talking and conversing, of the area of Foreign Language. The task has been designed bearing in mind the interests of the pupils and the reality, that is to say, their environment, with the aim to activate the capacities and skills of the pupil and to value their degree of acquisition of the oral competence. Every test was realized individually and it consisted of two parts: phase of interaction, in which a dialogue took place about school between the examiner and the pupil; and phase of production, where the task John's typical day was applied to evaluate the oral production. 
Table 1. Expression and oral interaction: dimensions, indicators and marks

\begin{tabular}{llll}
\hline Personal Questions & Marks & Indicators & Dimensions \\
\hline What time do you start school? & $0-4$ & Interaction & Communicative skills \\
How do you go to school? & $0-4$ & Organization and coherence & \\
What's your favourite subject? & $0-4$ & Rhythm, entonation and pronunciation & Verbal skills \\
What sports do you play at school? & & & \\
$\begin{array}{l}\text { Tell me about your best friend at school. } \\
\text { John's typical day. }\end{array}$ & $0-4$ & Fluency & Use of language \\
Continue the description of John's typical day. & $0-4$ & Grammar & \\
& $0-4$ & Vocabulary & \\
\hline
\end{tabular}

The validity of the instrument was done by the criteria of five experts according to three indicators: appropriateness, relevancy and uniqueness. The questionnaire went through three reviews before the definite version with the mentioned criteria. The reliability across Cronbach's alfa showed that with 49 elements was 0.735. The scale was administered by the investigators who gathered also aspects as the familiar environment, the dedication or the support to the study, the attitude towards the English subject and the results of the oral expression and oral interaction. Undoubtedly, the essence of the learning of any language is the aptitude to be able to communicate using it. In the latter part the capacity of the pupil to express correctly and with a minimal coherence in English is evaluated, as well as that of being able to maintain a short conversation on a familiar topic for the pupil, in this case, the school.

\section{Results}

\subsection{General Data of the Sample}

We analyse the sample taking into account the age, the gender, the geographical origin (rural or urban), and the previous programs in which students have studied (ordinary or bilingual schools). This way we have that the $41.4 \%$ of the total of the sample of 11 years are boys (53 students), whereas the other $58.6 \%$ are girls (75 students). The male pupils who compose the group of 12 years represent $47 \%$ (55 students) and the female pupils $53 \%$ (62 students). The group of 13 years is composed by 53\% of boys (10 students) and $47 \%$ of girls (9 students). If we take into account the type of school, rural or urban, we have a very equitable distribution because 55.5\% comes from public urban centers (147 students) and 44.5\% belongs to public rural schools (118 students). Likewise, the study has been carried out in public schools of ordinary and bilingual education. The sample of our study is divided, consequently, in four strata: public urban ordinary schools (12\%), public urban bilingual schools (43\%), rural ordinary schools (31\%) and rural bilingual schools (14\%). Science and Arts are the subjects studied in English in all bilingual centers (150 pupils) that are part of the study.

\subsection{Global Results of the Oral Expression and Oral Interaction}

An increasing scale of values has been designed from 0 to 5 to evaluate the level of achievement in oral expression and oral interaction and to classify the different levels of achievement reached by the students of sixth grade of Primary Education under oral expression and oral interaction in English.

Table 2. Oral expression and oral interaction: level of achievement

\begin{tabular}{lll}
\hline Level of achievement & Marks & Code \\
\hline Non-significant & 0 & 0 \\
Very deficient & $1-4$ & 1 \\
Deficient & $5-9$ & 2 \\
Intermediate & $10-14$ & 3 \\
Good & $15-19$ & 4 \\
Excellent & $20-24$ & 5 \\
\hline
\end{tabular}


The results register that students show a very positive level of oral expression and oral interaction. Almost the totality of the sample got positive results (43 students; 93\%). Only 7\% got low levels (3 students), being non-existent the values in the levels very deficient or non-significant. According to gender, the number of female pupils is higher than the number of male pupils, this way in the excellent level the female pupils register 30.4\% (14 students) and the male pupils $21.7 \%$ (10 students). Bearing the type of center in mind, the public bilingual centers stand out in the excellent level with $21.7 \%$ followed by the students of public rural bilingual centers (8 students). The highest percentage is placed in the intermediate level with $24 \%$ (11 students) of students enrolled in schools in public rural ordinary centers. The highest percentage in the excellent level is represented by the pupils of public urban bilingual centers, being the totality of the sample of this type of center the one that is registered in the above mentioned level (10 students; 100\%).

\section{Conclusions}

The obtained information in relation to the oral competence in English aims that the levels of achievement of students of León's Province are over the intermediate level. This way, more than half of the sample (52.2\%) reaches the highest level, excellent level. The results obtained in our empirical study do not correspond with the generalised belief by different studies realised by the Council of Europe and the Department of Education and Science that hold that Spain continues being in Europe's tail in terms of learning a foreign language.

Differences exist in the level acquired in linguistic communicative competence in English language between ordinary and bilingual centers. We coincide with Genesee (1987) that the benefits of the bilingual education do not manage to obtain until the pupils of bilingual educations reach the sixth grade, moment in which their capacities of transfer and their cognitive skills develop already with fullness. It is in the oral expression and oral interaction where the most important differences are obtained since $90 \%$ of the pupils who study in bilingual centers obtain a punctuation of 5 (excellent level) and level 4 (good level) only the $1 \%$ remaining. Only $23 \%$ of the pupils of ordinary centers obtains the level 5 (excellent level), being practically the half of the sample (46.2\%) in the level 3 (intermediate level). According to the answers of the interviewed teachers, more importance is given to the communication and to the interaction in the bilingual education (Coyle et al., 2010). In our study, a positive impact is revealed in speaking and conversing.

Differences exist in the level of achievement of the linguistic communicative competence in English between male pupils and female pupils since girls obtain better results than boys. Burstall (1975) demonstrates that women show a more favorable attitude than men and also, women achieve better results inside the academic context. Finally, in the levels good and excellent the percentage of male pupils is $68.4 \%$ and that of female pupils is $70.4 \%$. Consequently differences exist in the level of achievement of the linguistic communicative competence between male pupils and female pupils, coinciding with Lahuerta Martínez (2014).

Obviously, the pupils who dedicate more time to the revision and study of the English subject obtain better results in the acquisition of the linguistic communicative competence in oral expression and oral interaction. Pupils who dedicate enough and a little time to the study of the English subject (39\%) got the highest percentages in the excellent level. Surprisingly, the assistance to English particular lessons does not influence the results of the students' linguistic communicative competence in English, unlike the belief extended that private lessons guarantee improvement in English.

According to pupils' behaviour aspects, the results show the existence of a positive relation between the behaviour variable and the level of achievement in the evaluated competence. The emotion is defined as an essential component of the cognition in diverse studies on the acquisition of languages and it is also considered that emotion and cognition cannot be separated (Arnold, 2000). The approaches are different according to the variety of the affective dimension. It can influence both personal factors and individual differences (Rodríguez Perez, 2014). Some authors emphasize, between the different affective variables, the attitude that the pupils show towards the knowledge of the new language (Gardner \& Lambert, 1972), others emphasize the importance in the learning process of the emotional pupil's conditions (Oxford \& Shearin, 1994). In this study, the attitude towards the subject and towards the teacher are positive attitudes, as well as the study of the language coinciding with Pavón Vazquez’s study; Prieto Molina and Avila López’s study (2015). In oral expression and oral interaction, the percentage of major competition corresponds to the pupils who like the subject and the teacher a lot who got excellent level.

Taking into account the linguistic skills, the achievements obtained in this test place over what is expected, since more than the half of the sample (52,2\%) reaches a level 5 (level of excellent achievement). It is necessary to add that none of the pupils of the sample obtains neither level 0 (non-significant level) nor level 1 (very deficient level). The pupils' average of the sample reaches a 4.1 value. It is a high value that allows us to affirm that 
students, in a high percentage, dominate the linguistic oral skill. On the other hand, the distribution of partial qualifications (interaction, organization and coherence, rhythm, intonation and pronunciation, fluency, grammar and vocabulary) indicate that the pupils reach the highest average in the cognitive sub dimension that includes the rhythm, the intonation and the pronunciation followed of organization and coherence. The results improve lightly in the sub dimensions of fluency and of interaction.

As discussion, we indicate the confirmation of positive aspects as the attitude towards the language and the level acquired in all kinds of studied schools, as well as the positive influence of the bilingualism in the learning of the English language, besides a good global general competence detected. Other aspects that are also confirmed are the best competence of the female pupils and the preeminence of the public urban schools. Contrary to the awaited result, attending private English lessons once or twice per week does not improve the oral competence.

Though the sample is wide, we consider that extending the national study might change some of the conclusions, but globally the study's results would be very similar to the obtained ones.

\section{References}

Arnal, J., Del Rincón, D., \& Latorre, A. (1992). Investigación educativa. Fundamentos y metodología. Barcelona: Labor.

Arnold, J. (2000). La dimensión afectiva en el aprendizaje de idiomas. Madrid: Cambridge University Press.

Aymerich, C. (1971). Pedagogía de la expresión. Ciudad Real: Ñaque Editora, 2001.

Bisquerra, R. (1989). Métodos de investigación educativa. Guía práctica, Madrid Ceac.

Buendía Eisman, L., Colás Bravo, Mª. P., \& Hernández Pina, F. (1998). Métodos de investigación en psicopedagogía. Madrid: McGraw-Hill.

Burstall, C. (1975). Primary French in the balance. Educalional Research, 17, 193-198. https://doi.org/10.1080/0013188750170304

Canale, M., \& Swain, M. (1980, versión en español de 1996). Fundamentos teóricos de los enfoques comunicativos, en Signos, 17 y 18.

Cañas, J. (2000). Hablemos juntos. Barcelona: Octaedro.

Chomsky. (1965, ed. española 1997). Aspectos de la teoría de la sintaxis. Barcelona: Gedisa.

Chomsky, N. (1957). Syntactic structures. La haya: Mounton (Trad. Cast. Estructuras sintácticas). México: Siglo XXI, 1974.

Colás Bravo, Mà. P., Buendía Eisman, L., \& Hernández Pina, F. (2009). Competencias científicas para la realización de una tesis doctoral: Guía metodológica de elaboración y presentación. Barcelona: Editorial Davinci.

Comisión Europea. (2004). Competencias clave para un aprendizaje a lo largo de la vida. Un marco de referencia europeo. Puesta en práctica del programa de trabajo "Educación y Formación 2010”, Grupo de trabajo B “Competencias Clave”, Noviembre.

Comité Económico y Social Europeo. (2006). Dictamen del Comité Económico y Social Europeo sobre la «Propuesta de Recomendación del Parlamento Europeo y del Consejo sobre las competencias clave para el aprendizaje permanente». Diario Oficial de la Unión Europea.

Consejo de Europa. (2002). Marco Común Europeo de Referencia para las Lenguas: Aprendizaje, enseñanza, evaluación. Madrid: Ministerio de Educación, Cultura y Deporte, Instituto Cervantes y Editorial Anaya.

Corominas, E. (2006). Percepciones del profesorado ante la incorporación de las competencias genéricas en la formación universitaria. Revista de Educación, 341, 301-336.

Coyle, D., Hood, P., \& Marsh, D. (2010). CLIL: Content and Language Integrated Learning. Cambridge: CUP.

Creswell, J. (2002). Educational Research: Planning, conducting, and evaluating quantitative research. Ohio, Merrill Prentice Hall.

Díaz, A. (2006). El enfoque de competencias en la educación. Una alternativa o un cambio de disfraz? Perfiles Educativos, XXVIII(111), 7-36.

Fernández-Salinero, C. (2006). Las competencias en el marco de la convergencia europea: Un nuevo concepto para el diseño de programas educativos. Encounters on Education, 7, 131-153. https://doi.org/10.15572/enco2006.07 
García Doval, F., Guillén, C., González Piñeiro, M., González Porto, J., Serna, I., \& Vez, J. M. (2004). Marco y Portafolio: Porta linguarum para los europeos. In Porta Linguarum. Revista Internacional de Didáctica de las Lenguas Extranjeras (No. 2, pp. 69-92).

Gardner, R. C., \& Lambert, W. E. (1972). Attitudes and Motivation in Second-Language Learning. Rowley: Newbury House Publishers.

Genesee, F. (1987). Learning through Two Languages: Studies of Immersion and Bilingual Education. Rowley, MA: Newbury House.

Hernández Pina et al. (2008). El proceso de investigación y el análisis de datos en Ciencias Sociales. Murcia: DM.

Hymes, D. (1971). Foundations in sociolinguistics: An ethnographic approach (Reprinted in 2001 by Routledge). International Journal of Cross Cultural Management, 6.

Lahuerta Martínez, A. C. (2014). Analysis of the Effect of Content Familiarity and Gender on English as a Foreign Language Reading Comprehension by Spanish University Students Porta Linguarum: Revista internacional de didáctica de las lenguas extranjeras (No. 21, pp. 69-84).

Latorre, A., Rincón, D. D., \& Arnal, J. (2005). Bases Metodológicas de la Investigación Educativa. Experiencia S. L., Barcelona.

Ley Orgánica de Educación (LOE). (2006). de 3 de mayo, B.O.E. del 4 de mayo de 2006.

Ley Orgánica para la Mejora de la Calidad Educativa (LOMCE). (2013). de 9 de diciembre, B.O.E. nº 295 de 10 de diciembre de 2013.

López Valero, A., \& Encabo, E. (2001). Mejorar la comunicación en niños y adolescentes. Madrid: Pirámide.

Ministerio de Educación Y Ciencia. (2006). Currículo y competencias básicas.

Monfort, M. (1995). Enseñar a hablar. IV Simposio de Logopedia. Madrid: CEPE.

Murillo, F. J., Martínez-Garrido, C., \& Hidalgo, N. (2014). Incidencia de la forma de evaluar los docentes de Educación Primaria en el rendimiento de los estudiantes en España. Estudios sobre Educación, 27, 91-113. https://doi.org/10.15581/004.27.91-113

Nikeva, D. G., \& Cortina Pérez, B. (2014). La producción científica actual en Didáctica de la Lengua y la Literatura en revistas españolas (pp. 281-299).

Noguera, J. (2004). Las competencias básicas. Retrieved from http://www.redescepalcala.org/inspector/DOCUMENTOS\%20Y\%20LIBROS/COMPETENCIAS/LAS\%20 COMPETENCIAS\%20BASICAS\%20-\%20NOGUERA.pdf

OCDE. (2002). Proyecto DeSeCo: Définitions et sélection des compétences. In Fondements théoriques et conceptuels, Document de strategie.

OCDE. (2003). La definición y selección de competencias clave. In Resumen ejecutivo.

Oxford, R., \& Sherin, J. (1994). Language Learning Motivation: Expanding the Theoretical Framework. The Modern Language Journal, 78, 12-28. https://doi.org/10.1111/j.1540-4781.1994.tb02011.x

Palou, J., \& Bosch, C. (coord.). (2005). La lengua oral en la escuela: 10 experiencias didácticas. Barcelona: Graó.

Pavón Vazquez, V., Prieto Molina, M., \& Ávila López, F. J. (2015). Perceptions of Teachers and Students of the Promotion of Interaction Through Task-Based Activities in CLIL (pp. 75-91).

Pérez Esteve, P. (2008). La comprensión lectora y la competencia en comunicación lingüística en el nuevo marco curricular: Algunas claves para su desarrollo. CEE Participación Educativa, 41-56.

Perrenoud, P. H. (2012). Cuando la escuela pretende preparar para la vida. Desarrollar competencias o enseñar otros saberes? Barcelona: Graó.

Piaget, J. (1983a). A propósito del núcleo fijo y de su innatismo: “Observaciones introductorias”. In M. Piatelli-Palmarini (org. y recop.), Teorías del lenguaje. Teorías del aprendizaje (pp. 89-94). Barcelona: Crítica.

Piaget, J. (1983b). Esquemas de acción y aprendizaje del lenguaje. In M. Piatelli-Palmarini (org. y recop.), Teorías del lenguaje. Teorías del aprendizaje (pp. 210-214). Barcelona: Crítica.

Pinker, S. (2003). El instinto del lenguaje. Madrid: Alianza Editorial. 
Quiles, M. C. (2006). La comunicación oral. Propuestas didácticas para la Educación Primaria. Barcelona: Octaedro.

Ramos, M. M., \& Luque, G. (2010). A competence-based constructivist tool for evaluation. Cultura y Educación, 22(3), 329-344. https://doi.org/10.1174/113564010804932148

Rodríguez Pérez, M. N. (2014). Creencias y representaciones de los profesores de lenguas extranjeras sobre la influencia de los factores motivacionales y emocionales en los alumnos y en las alumnas (pp. 183-198).

Sapir, E. (1921). An introduction to the study of speech. New York: Harcourt.

Stoof, A., Marten, R., Van Merrienboer, J., \& Bastiens, T. (2002). The Boundary Approach of Competence: A Constructive Aid for Understanding and Using the Concept of Competence. Human Resource Development Review, 1(3), 345-365. https://doi.org/10.1177/1534484302013005

Tejedor, J. (1999). Análisis de Varianza. Madrid: La Muralla.

Vygotski, L. S. (1992). Pensamiento y lenguaje. Buenos Aires: La Pléyade.

Westera, W. (2001). Competences in Education: A Confusion of Tongues. Journal of Curriculum Studies, 33(1), 75-88. https://doi.org/10.1080/00220270120625

Zuccherini, R. (1992). Cómo educar la comunicación oral. Barcelona: Ceac.

\section{Copyrights}

Copyright for this article is retained by the author(s), with first publication rights granted to the journal.

This is an open-access article distributed under the terms and conditions of the Creative Commons Attribution license (http://creativecommons.org/licenses/by/4.0/). 